\title{
UNREGULATED CATCHES FROM RECREATIONAL FISHERIES OFF NORTHEASTERN BRAZIL
}

\author{
KÁTIA M. F. FREIRE \\ Universidade Federal do Rio Grande do Norte - Departamento de Oceanografia e Limnologia - Praia de Mãe Luíza, S/N - Mãe Luíza - \\ CEP: 59014 - 100 - Natal - Rio Grande do Norte - Brasil. kfreire2006@yahoo.com.br
}

\section{CAPTURAS NÃO REGULADAS PROVENIENTES DA PESCA RECREATIVA DO NORDESTE DO BRASIL}

Estimativas globais acuradas das capturas provenientes da pesca recreativa não existem, uma vez que a maior parte dos países não tem a obrigação de registrar as capturas das atividades recreativas. Um aumento do conhecimento sobre o impacto da pesca recreativa que, em alguns casos, pode superar o impacto da pesca comercial, tem levado alguns países a coletar informações sobre as capturas recreativas. Tal sistema ainda é inexistente em países tais como o Brasil. A pesca recreativa no nordeste do Brasil é principalmente costeira e estruturada em torno de clubes de pesca, os quais promovem anualmente mais de 100 torneios de pesca. Estes torneios são realizados durante todo o ano, mas são menos freqüentes durante a estação chuvosa e com ventos intensos (julho a setembro), e durante a época das férias locais (dezembro a janeiro). As capturas destes torneios atingiram um pico de três toneladas em 1998. Não existe informação detalhada sobre as capturas por espécie. Estas estimativas de capturas de torneios são preliminares, uma vez que não incluem todos os estados nem a pesca oceânica.

PALAVRAS CHAVE: Pesca recreativa, pesca esportiva, pesca amadora, campeonatos de pesca.

\section{ABSTRACT}

Accurate global estimates of recreational catches are missing, as most countries do not have the mandate to report catches from recreational activities. Increasing awareness of the impact of recreational fisheries, which in some cases can surpass that from commercial fisheries, has led some countries to collect information on recreational catches. Such a system is still lacking in countries such as Brazil. Recreational fisheries in northeastern Brazil are mainly shore-based and structured around fishing clubs, which promote more than 100 fishing tournaments annually. These tournaments are run year-round, but are less frequent during the rainy, windy season (July to September) and the local holiday season (December to January). Catches from these tournaments amounted to a peak of three tonnes in 1998, which added to the previously estimated 1,147 tonnes caught outside tournaments, are much lower than those from commercial fisheries (131 thousand tonnes). There is no detailed information on catches per species. These estimates of tournament catches are preliminary, as they do not include all States and oceanic fisheries.

KEY WORDS: recreational fishery, sport fishery, amateur fishery, fishing tournaments.

\section{INTRODUCTION}

Alverson et al. (1994) estimated that global bycatches and discards could amount to about 27 million tonnes annually. This document created an awareness that total global marine catches had already reached a peak of 100 million tonnes and, in fact, have been declining in the last years, after the unrealistic high Chinese catches are properly corrected (Watson \& Pauly 2001). Moreover, FAO estimated that illegal, unregulated, and unreported (IUU) catches make up roughly $30 \%$ of global catches (FAO 2001).

Recreational catches would be included in the unregulated category of IUU, as most countries do not have the mandate to report catches originating from recreational activities. Some rough estimates indicate that global recreational catches may vary between 2 (Coates 1995) and 10.9 million tonnes (Cooke \& Cowx 2004). Although the totals are much lower than total catches generated by commercial fisheries, recreational catches may surpass the latter in some cases. In the United States, for example, seven out of the ten top species caught by anglers result in catches higher than commercial fisheries (Gentner \& Lowther
2002). For threatened species, this impact is considerable (Coleman et al. 2004).

There is no information available on recreational catches off northeastern Brazil, with the exception of recent estimates by Freire (2005) indicating that catches outside fishing tournaments may amount to an average of 1,147 tonnes annually. The objective of this paper is to estimate recreational catches from fishing tournaments promoted in northeastern Brazil, which will be used to complement the previous estimate and would allow for better management of recreational fisheries in consonance with commercial fisheries.

\section{METHODS}

Fishing clubs were visited in seven of the nine states of northeastern Brazil during June-July 2001: Maranhão, Ceará, Rio Grande do Norte, Paraíba, Pernambuco, Sergipe, and Bahia (Fig. 1). Two states were not visited due to time constraints (Piauí and Alagoas). Presidents and/or vice-presidents of these clubs provided results of fishing tournaments promoted by their clubs since their establishment. Data provided were very heterogeneous and included: (1) 'points' 
obtained by each angler, i.e., a combination of total number and weight of fish caught; (2) total number and total weight of fish caught by all anglers combined; (3) total number and total weight of fish caught by each angler (not broken down by species); and (4) number of fish caught by each angler broken down by species and total weight of all species combined.

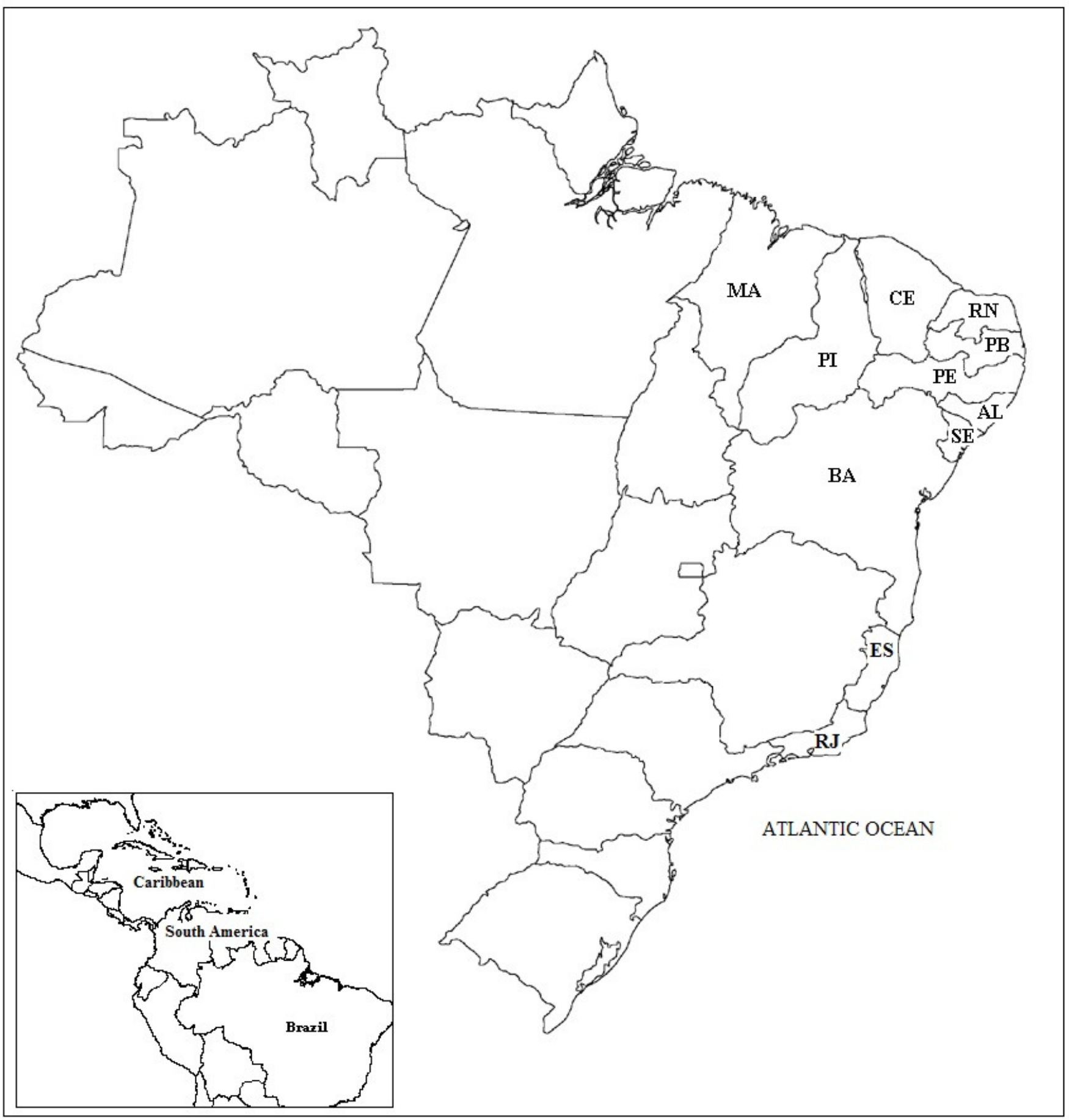

FIGURE 1: Political division of Brazil, showing details of the nine States in the northeastern region. $M A=$ Maranhão, $\mathrm{PI}=$ Piauí, $\mathrm{CE}=$ Ceará, $\mathrm{RN}=$ Rio Grande do Norte, $\mathrm{PB}=$ Paraíba, $\mathrm{PE}=$ Pernambuco, $\mathrm{AL}=$ Alagoas, $\mathrm{SE}=$ Sergipe , and $\mathrm{BA}=$ Bahia. $\mathrm{ES}=$ Espírito Santo and $\mathrm{RJ}=$ Rio de Janeiro are part of the southeastern region. 
Data presented here represent a combination of weight from (2), (3) and (4) above from all fishing tournaments promoted by each club from 1970 to 2000 in marine waters off four States from northeastern Brazil: Ceará, Rio Grande do Norte, Paraíba, and Sergipe. For those years where no data was available, an average value was estimated based on data for the previous and following years. If more than one value was missing, they were estimated based on the observed trend. For the earliest years, if there was no clear trend, an annual increase in catches of $10 \%$ was assumed based on the assumption that earlier tournaments may have produced lower catches due to lack of experience and less attractiveness of the first events. Higher increase rates led to unrealistically low catch values ( $\leq$ zero) for the first tournaments. The overall basic assumption was that all fishing tournaments were promoted annually unless otherwise stated.

The Brazilian Fishing and Aquatic Sports Confederation - CBPDS is the national agency responsible for organizing tournaments promoted by fishing clubs officially recognized by this confederation (http://www.cbpds.org.br/cbpds/). Several 'non-official' clubs organize their own fishing tournaments and catches estimated here are originating from both official and non-official tournaments. In this paper, fishing tournaments are considered as synonymous with tacking tournaments or competitive fishing and are defined as "organized events in which a group of anglers fish for inducements - awards, prizes, or public recognition - in addition to the catch or the satisfaction of catching fish" (Schramm Jr. et al. 1991).

\section{RESULTS AND DISCUSSION}

According to Bezerra (1994), Pâmpano Esporte Clube was the first fishing club to be established in northeastern Brazil. This club began its activities in 1954, in the state of Rio Grande do Norte, and has been quite active since then, promoting several fishing tournaments. In fact, the Clube de Amadores de Pesca Viriato de Medeiros was established one year before, in the state of Pernambuco. Also in Pernambuco, the Cabanga late Clube de Pernambuco was launched in 1947 and had several members taking part in underwater fishing. This club got involved in oceanic sport fisheries much later (1990s). Several other fishing clubs were established in the region, particularly after the 1980s (Table 1), with a total of 45 fishing clubs in the region. This number should be considered a minimum estimate as anglers mentioned the establishment of other clubs, but no one was able to remember when they were established. These clubs and fishing federations (in the states of Ceará, Rio Grande do Norte, Paraíba, Pernambuco, and Bahia) have promoted several 1-3 day fishing tournaments with up to 133 participants. Activity was more intense between 1995 and 1998 when about 100 events were promoted annually (Fig. 2). The trend for earlier years is likely to be biased due to the lack of documents reporting the results of the tournaments. Furthermore, there is no record for tournaments promoted prior to 1970 . Events take place year-round (Fig. 3), but the rhythm slows down from July to September probably due to the rainy and windy season, and also from December to January, when it is more difficult to have high attendance due to the holiday season. The degree of activity observed in northeastern Brazil is much lower than the 978 annual events estimated for North American marine waters in 1989 (Schramm Jr. et al. 1991) or the much more frequent freshwater tournaments (25,000 events year-1 in 2000/2001; Kerr \& Kamke 2003). 
Table 1: Lifespan of fishing clubs and associations involved with recreational fisheries in northeastern Brazil (1947-2009)*.

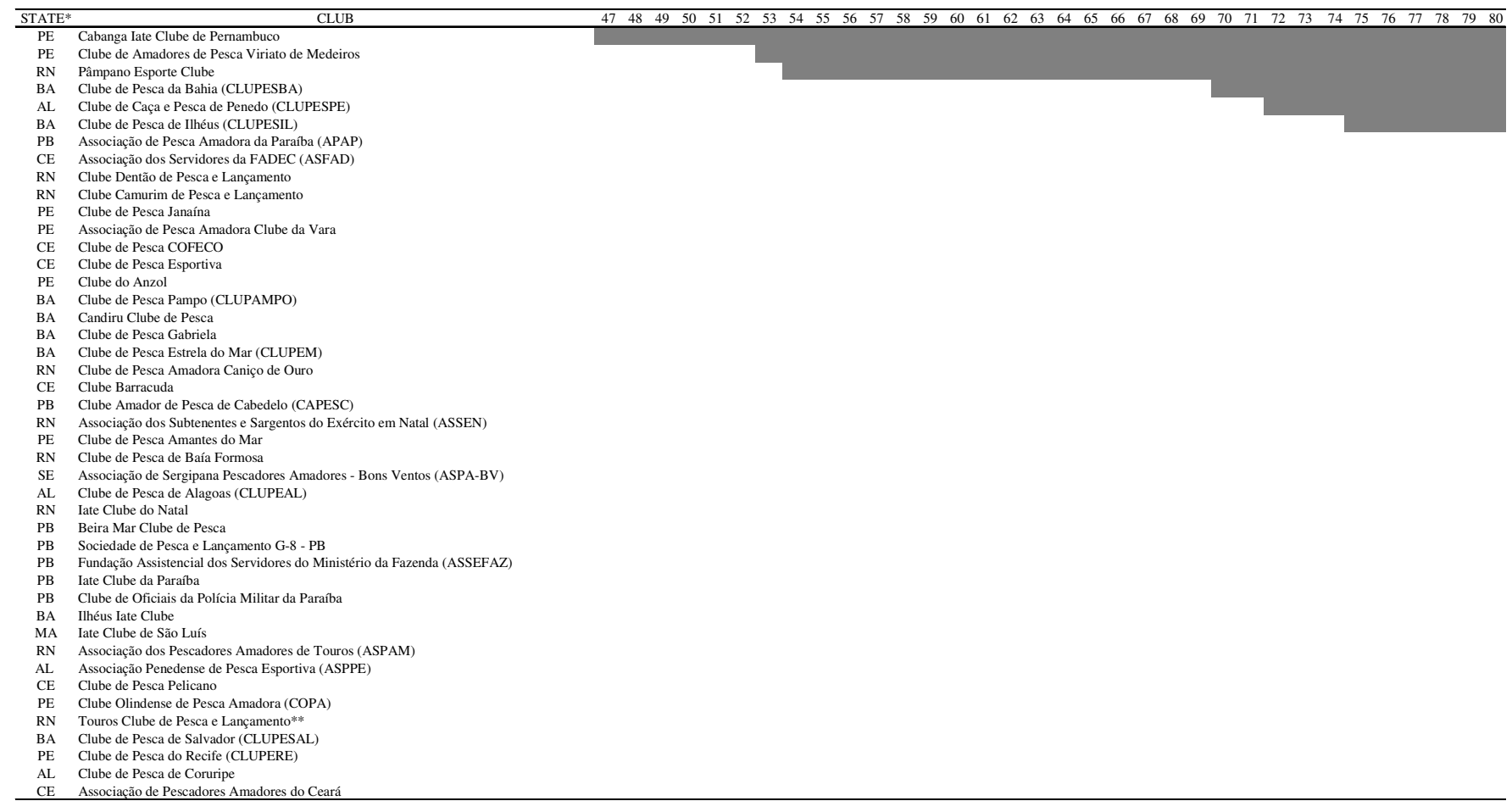

CE Associacão de Pescadores Amadores do Ceará

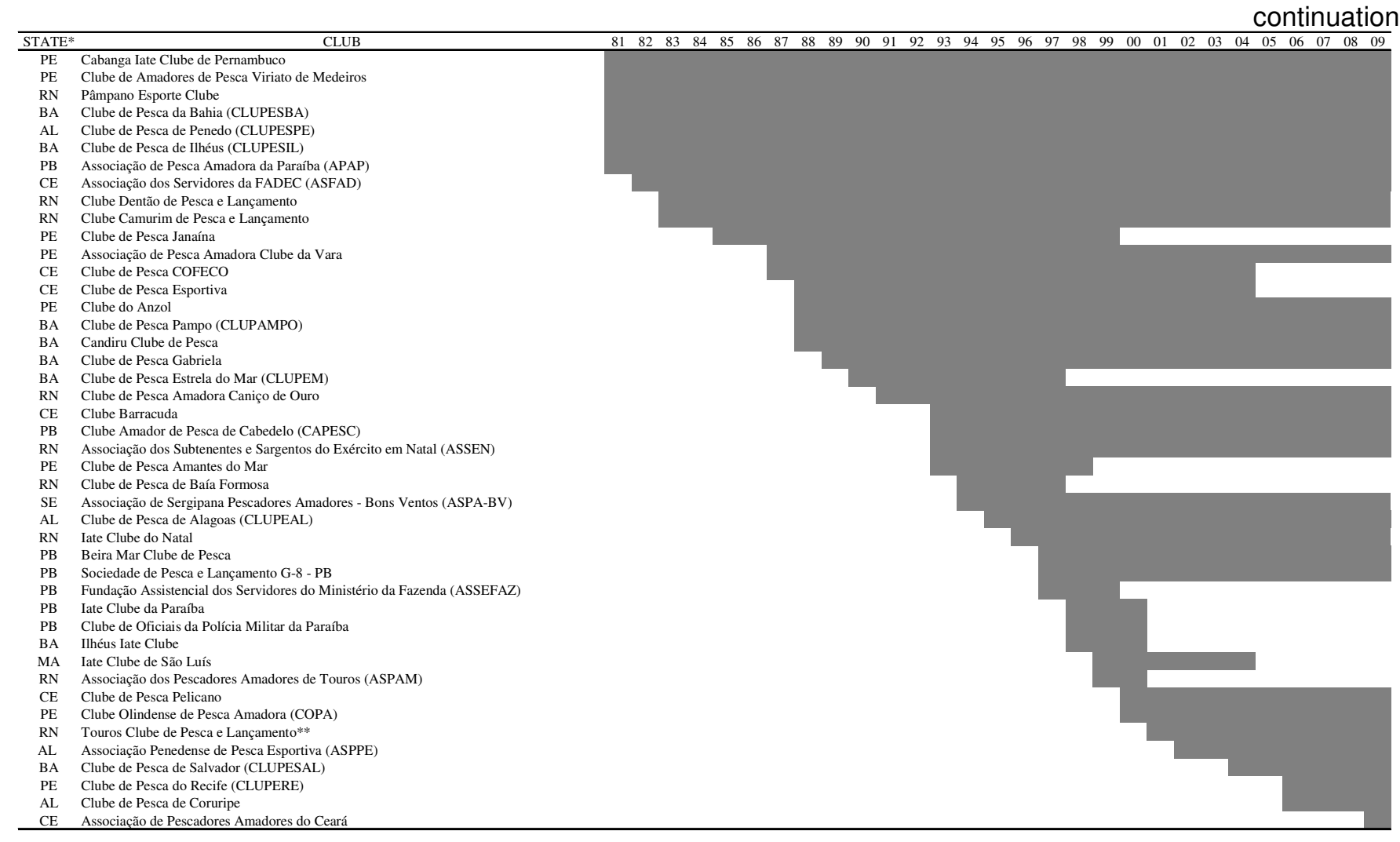




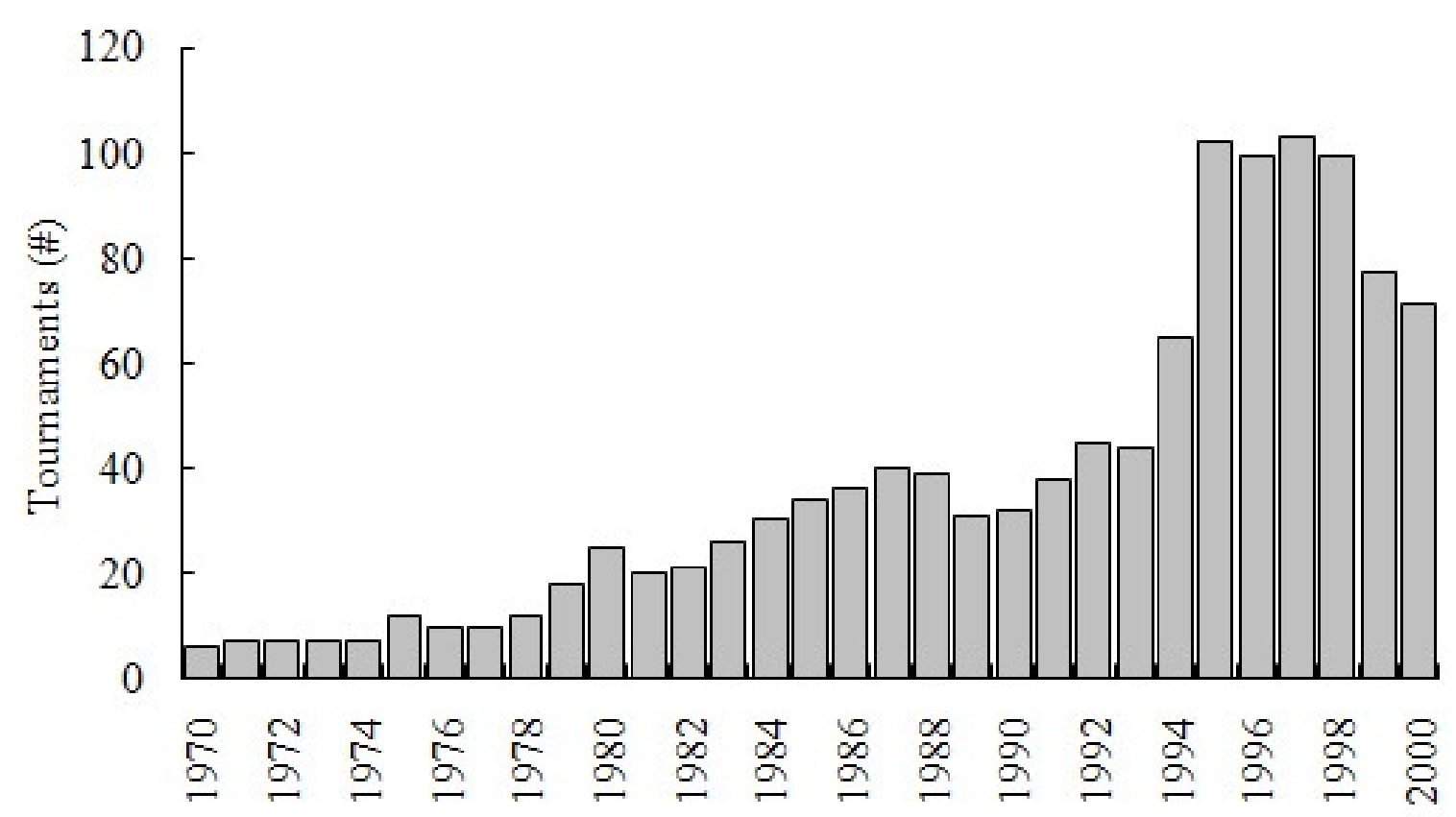

FIGURE 2: Total number of fishing tournaments promoted in northeastern Brazil from 1970 to 2000 (Ceará, Rio Grande do Norte, Paraíba, and Sergipe States).

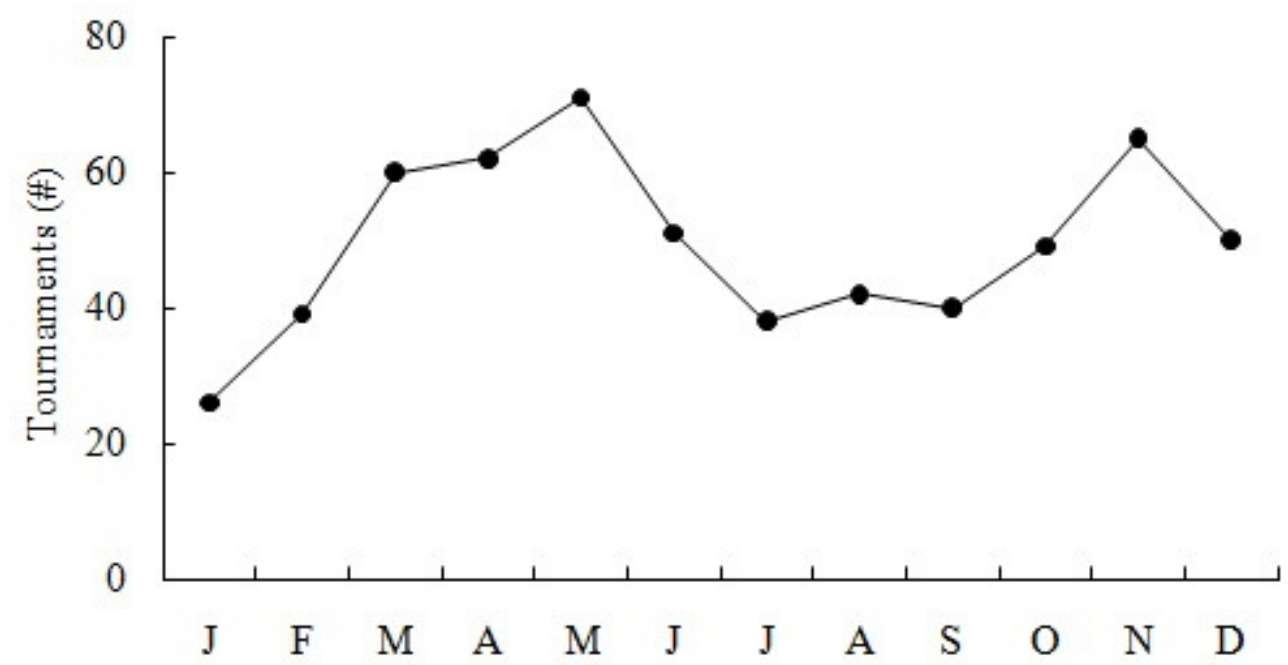

FIGURE 3: Total number of fishing tournaments promoted in northeastern Brazil per month (January to December 1970 to 2000$)$.

All available records indicate that up to 2.2 tonnes of fishes were caught annually in fishing tournaments in four states in northeastern Brazil (Fig. 4). After correcting for catches from tournaments for which no document was available (using the methodology described above), total catches increased to a peak of more than 3 tonnes in 1998 and decreased to 1.9 tonnes in 2000 . The latter estimate added up to catches of 1,147 tonnes estimated for the same region for daily activity of anglers (tournaments excluded) (Freire 2005), indicates that recreational fisheries are not exerting a strong pressure on local resources when compared with commercial fisheries (artisanal and industrial), which landed 137 thousand tonnes in 2000 (Freire, 2003). These results are partial, as they do not include all states in the northeastern region or oceanic fishing tournaments. 


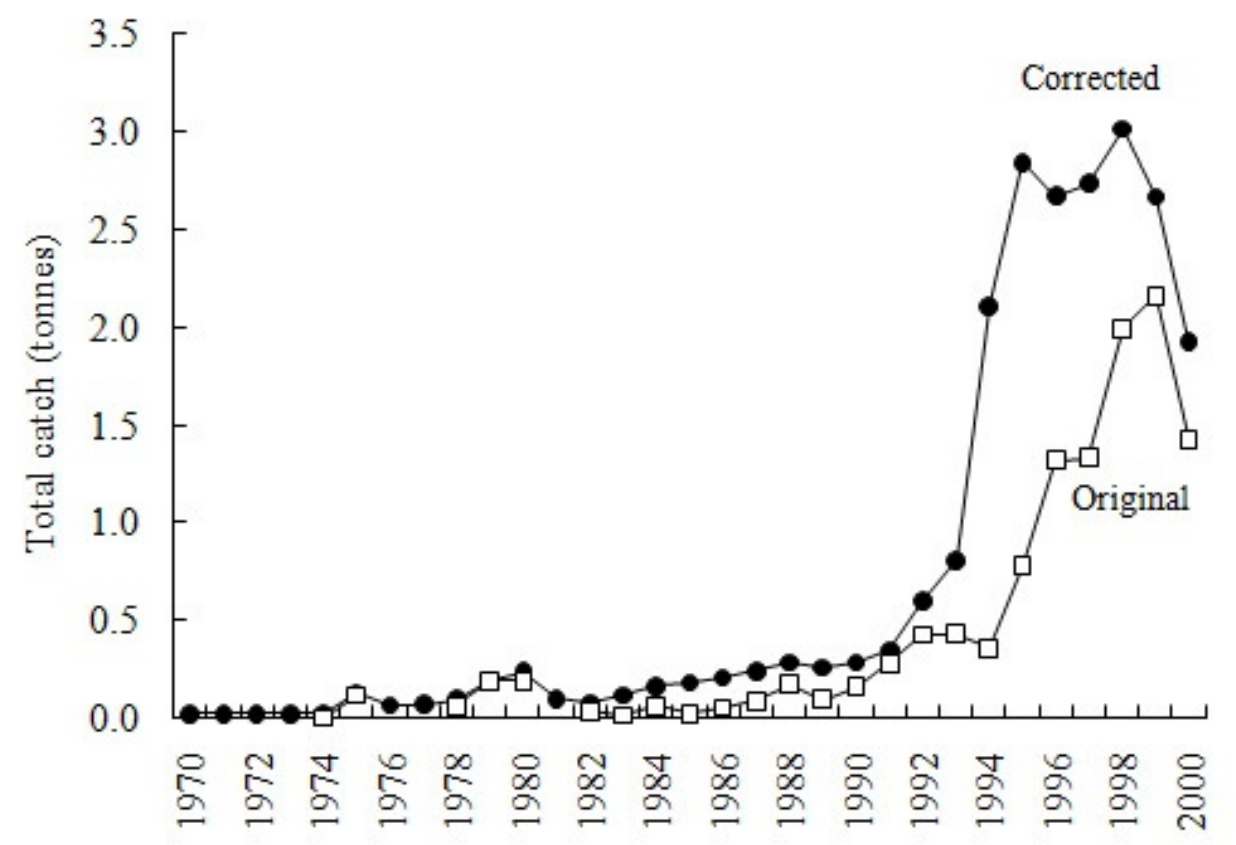

FIGURE 4: Total catch from fishing tournaments promoted in northeastern Brazil from 1970 to 2000 (Ceará, Rio Grande do Norte, Paraíba, and Sergipe States). 'Original' refers to tournaments from with results were readily available and 'Corrected' refers to catches corrected for missing documents based on observed trends.

Catches originating from shore-based fishing tournaments in northeastern Brazil usually are not split by species, with the exception of those promoted in earlier years by the Pâmpano Esporte Clube. Thus, no detail about catches per species could be provided here. However, there is an indication of the main species caught in the region, based on questionnaires and record of the heaviest fish caught by each angler in each fishing tournament: catfish (Ariidae), threadfins (Polydactylus spp.), rays (unidentified), jacks (Caranx spp.), pompanos (Trachinotus spp.), kingcroakers (Menticirrhus americanus and $M$. littoralis), puffers (unidentified), snooks (Centropomus spp.), king mackerel (Scomberomorus cavalla), sharks (unidentified), weakfish (Cynoscion spp.), barred grunt (Conodon nobilis), tarpon (Megalops atlanticus), jenny mojarra (Eucinostomus spp.), mutton snapper (Lutjanus analis), giant grouper (Epinephelus itajara), and yellowtail snapper (Ocyurus chrysurus) (Freire 2005).

According to the Federal regulation N. 30 of May $23^{\text {rd }} 2003$ (IBAMA - Brazilian Institute for the Environment and Renewable Resources), all organizers had to obtain a license for each fishing tournament promoted in Brazil and to report the results of each event, including catch per species, within 15 days after its closure. This requirement would theoretically provide better future estimates of catches originating from recreational activities. However, in practical terms, there was some difficulty in implementing this policy as organizers were not willing to record catches per species due to time constraints (personal observation). After the creation of the Ministry of Fisheries and Aquaculture (MPA), the license for fishing tournaments has to be obtained from the MPA (Federal regulation N. 1 of August $28^{\text {th }} 2009$ ).

Information about catches from Brazilian marine recreational fisheries is available in the literature only for fishing tournaments off Rio de Janeiro, São Paulo and Espírito Santo (southeastern Brazil). In Rio de Janeiro, catches were recorded by species and accounted for about 33 t.year ${ }^{-1}$ from 1969 to 1992 (Paiva \& Pires-Júnior 1983, Arfelli et al. 1994). However, these estimates originate from a single fishing club, the 'late Clube do Rio de Janeiro', which has promoted annually a single season-long oceanic tournament since 1963 (Barroso 2002). A total of 4 tonnes of billfishes were caught in 1990 off Espírito Santo (Jorge et al. cited in Arfelli et al. 1994), originating from fishing tournaments promoted by a single fishing club. No information regarding catches from fishing tournaments was found for other areas in 
Brazil or South America, with the exception of Venezuela (Gaertner et al. 1989). However, these authors dealt only with billfishes caught in tournaments promoted by one single fishing club. It becomes clear that more attention has been devoted to catches of billfishes and other large pelagic fishes, probably due to the attractiveness of those 'big fishes' and the economic value associated with such oceanic fisheries, and little is known about shore-based recreational fisheries.

\section{ACKNOWLEDGEMENTS}

I would like to thank all fishing clubs listed in Table 1 and fishing federations for collaborating with this study; Juarez Rodrigues for helping to encode data on fishing tournaments; Elizabeth Mohammed and Patricia Keen for making suggestions to improve this paper; CNPq (Brazilian National Council for the Scientific and Technological Development) and The Sea Around Us Project for funding the fieldwork; and Alfredo Carvalho Filho and an anonymous reviewer for their valuable corrections and suggestions.

\section{CITED LITERATURE}

ALVERSON, DL, MH FREEBERG, SA MURAWSKI \& JG POPE. 1994. A global assessment of fisheries bycatch and discards. FAO Fish. Tech. Pap. 339: 1-233.

ARFELLI, CA, AF AMORIM \& R GRAÇA-LOPES. 1994. Billfish sport fishery off Brazilian coast. Col. Vol. Sci. Pap. ICCAT XLI: 214-217.

BARROSO, H. 2002. Tempos da pesca. Rio de Janeiro, Brazil, Ediouro. $248 \mathrm{p}$.

BEZERRA, LGM. 1994. A pesca emocionante de alto mar do Pâmpano. Pâmpano Esporte Clube. 40 anos (1954-1994). Edição comemorativa. Natal, Brazil: 21.

COATES, D. 1995. Inland capture fisheries and enhancement: status, constraints and prospects for food security, Kyoto, Japan KC/FI/95/TECH/3. Rome: FAO.

COLEMAN, FC, WF FIGUEIRA, JS UELAND \& LB CROWDER. 2004. The impact of United States recreational fisheries on marine fish populations. Science 305(5692): 1958-1960.

COOKE, SJ \& IG COWX. 2004. The role of recreational fishing in global fish crises. BioScience 54(9): 857-859.
I will be extending this work in order to include results from shore-based tournaments promoted by those States not considered up to now and from oceanic tournaments. I also recommend that a recording system should be implemented to allow for a systematic collection of catch data from these tournaments, including information per species. This system should be discussed with fishing clubs in order to succeed. Anglers' collaboration is essential to allow for a proper assessment of the importance of recreational fisheries in this region.

FAO. 2001. New International Plan of Action Targets Illegal, Unregulated and Unreported Fishing. Press Release 01/11.

FREIRE, KMF. 2003. A database of landing data on Brazilian marine fisheries from 1980 to 2000. Fish. Cent. Res. Rep. 11(6): 181-189.

FREIRE, KMF. 2005. Recreational fisheries of northeastern Brazil: inferences from data provided by anglers. In: KRUSE, GH, VF GALLUCCI, DE HAY, RI PERRY, RM PETERMAN, TC SHIRLEY, PD SPENCER, B WILSON \& D. WOODBY (eds.). Fisheries assessment and management in data-limited situations. Proceedings of the $21^{\text {st }}$ Wakefield Fisheries Symposium, October 22-25, 2003, Anchorage, Alaska, USA: 377-394.

GAERTNER, D, JJ ALIO \& R GARCIA DE LOS SALMONES. 1989. La pesca deportiva de los peces de pico en Venezuela. Analisis de los datos del club de Playa Grande (1961-1987). Col. Vol. Sci. Pap. ICCAT 30(2): 382-391.

GENTNER, B \& A LOWTHER. 2002. Evaluating marine sport fisheries in the USA. In: TJ Pitcher \& CE Hollingworth (eds.).Recreational fisheries: ecological, economic and social evaluation. Oxford, Blackwell Science Ltd:186-206.

KERR, SJ \& KK KAMKE. 2003. Competitive fishing in freshwaters of North America: a survey of Canadian and U. S. Jurisdictions. Fisheries 28(3): 26-31.

PAIVA, MP \& OC PIRES-JÚNIOR. 1983. Temporadas de pesca esportiva e oceânica, ao largo do estado do Rio de Janeiro. Bol. Ciênc. Mar. 38: 1-12.

SCHRAMM JR., HL, ML ARMSTRONG, NA FUNICELLI, DM GREEN DP LEE, RE MANNS JR., BD TAUBERT \& SJ WATERS. 1991. The status of competitive sport fishing in North America. Fisheries 16(3): 4-12.

WATSON, R \& D PAULY. 2001. Systematic distortions in world fisheries catch trends. Nature 414(6863): 534-536.

Recebido: 17/09/2008

Aceito: 15/12/2009 
